A N N A LES

UNIVERSITATIS MARIAE CURIE-SKŁODOWSKA

LUBLIN - POLONIA

VOL. LXIII, 2

SECTIO G

2016

Uniwersytet Marii Curie-Skłodowskiej w Lublinie

katarzyna.kopaczynska-pieczniak@poczta.umcs.lublin.pl

KATARZYNA KOPACZYŃSKA-PIECZNIAK

\title{
Dobre obyczaje i zasady współżycia społecznego w prawie spółek handlowych
}

Good Practices and Rules of Social Conduct in Corporate Law

\section{PODSTAWY NORMATYWNE STOSOWANIA KLAUZUL GENERALNYCH „DOBRE OBYCZAJE” I „ZASADY WSPÓŁŻYCIA SPOŁECZNEGO” W STOSUNKACH SPÓŁEK HANDLOWYCH}

W społecznej gospodarce wolnorynkowej szczególne znaczenie mają postawy wzajemnego zaufania, życzliwości, uczciwości i służebności w działalności gospodarczej ${ }^{1}$, czemu służy między innymi odwołanie się do systemów wartości wyrażanych przez dobre obyczaje czy zasady współżycia społecznego. Ich znaczenie jest szczególnie istotne $\mathrm{z}$ uwagi na częste zmiany w przepisach oraz dynamikę i złożoność stosunków prawnych powstających w obrocie gospodarczym, podlegających prawu handlowemu. Zastosowanie tych klauzul w prawie handlowym powinno przy tym uwzględniać specyficzny charakter stosunków prawnych powstających w obrębie przedsiębiorców $\mathrm{i}$ ich struktury organizacyjnej.

Wśród unormowań odsyłających do klauzuli generalnej dobrych obyczajów lub zasad współżycia społecznego można wyróżnić przepisy²:

- według których naruszenie tych norm wywołuje ujemne skutki prawne dla naruszającego (np. art. 5 , art. $58 \S 2$, art. $353^{1}$, art. $70^{5}$, art. $72 \S 2$, art. $385^{1}$

1 Z. Radwański, M. Zieliński, [w:] System Prawa Prywatnego, t. 1: Prawo cywilne - część ogólna, red. M. Safjan, Warszawa 2012, s. 397; L.V. Ryan, Wyzwania moralne w czasach transformacji gospodarczej, „Ruch Prawniczy, Ekonomiczny i Socjologiczny” 1996, nr 1, s. 45 i n.

2 Zob. A. Wolter, J. Ignatowicz, K. Stefaniuk, Prawo cywilne. Zarys części ogólnej, Warszawa 2001 , s. 73 i n. 
$\S 1$ k.c. ${ }^{3}$, art. 3 ust. 1 u.z.n.k. ${ }^{4}$, art. 4 u.p.n.p.r. ${ }^{5}$, art. $249 \S 1$, art. $422 \S 1$ k.s.h. ${ }^{6}$, art. $42 \S 3$ pr. spółdz. ${ }^{7}$ ),

- zgodnie z którymi powstanie, zmiana lub ustanie praw lub obowiązków zależy od ich oceny w świetle tych norm (np. art. $357^{1}$ i $358^{1} \S 3$, art. 411 pkt 2, art. 440 , art. $446 \S 2$ zd. 2 k.c., art. $304 \S 4$ k.s.h.),

- które wykorzystują dobre obyczaje lub zasady współżycia społecznego do bliższego sprecyzowania treści stosunku prawnego (art. 56, art. $65 \S 1$, art. 140 k.c.) bądź obowiązku (np. art. 17 u.s.d.g. ${ }^{8}$ ).

W przepisach dotyczących spółek handlowych, z uwagi na znaczenie zasady pewności i bezpieczeństwa obrotu, ustawodawca dość oszczędnie odwołuje się do klauzul generalnych. Stosuje natomiast technikę polegającą na odesłaniu w treści przepisów do pewnych zwrotów niedookreślonych, niebędących klauzulami generalnymi, takich jak ,ważne powody”, ,interes spółki”. W wielu przypadkach te bardziej szczegółowe odesłania eliminują potrzebę powołania się na klauzulę generalną, np. „dobrych obyczajów”. Można nawet zaryzykować stwierdzenie, że klauzula dobrych obyczajów pochłania pewne zwroty niedookreślone, gdyż w wielu przypadkach ocena dokonywana przez pryzmat takich zwrotów mogłaby również być dokonywana przy wykorzystaniu wskazanej klauzuli, a jednocześnie wynik tych ocen byłby taki $\mathrm{sam}^{9}$. Z kolei odesłania do klauzul generalnych zawarte są nie w przepisach ogólnych (np. w kodeksie spółek handlowych), lecz w regulacjach dotyczących konkretnych zagadnień, co powoduje zawężenie możliwości posłużenia się taką klauzulą i jednocześnie sprzyja konkretyzacji przedmiotu odniesienia pozaprawnego ${ }^{10}$.

W stosunkach spółek handlowych - zarówno wewnętrznych, jak i zewnętrznych - znajdzie zastosowanie i klauzula generalna zasad współżycia społeczne-

3 Ustawa z dnia 23 kwietnia 1964 r. - Kodeks cywilny (t.j. Dz.U. z 2014 r., poz. 121 ze zm.), dalej jako: k.c.

4 Ustawa z dnia 16 kwietnia 1993 r. o zwalczaniu nieuczciwej konkurencji (t.j. Dz.U. z 2003 r., nr 153, poz. 1503 ze zm.).

5 Ustawa z dnia 23 sierpnia 2007 r. o przeciwdziałaniu nieuczciwym praktykom rynkowym (Dz.U., nr 171, poz. 1206).

6 Ustawa z dnia 15 września 2000 r. - Kodeks spółek handlowych (t.j. Dz.U. z 2014 r., poz. 265 ze zm.), dalej jako: k.s.h.

7 Ustawa z dnia 16 września 1982 r. - Prawo spółdzielcze (t.j. Dz.U. z 2013 r., poz. 1443 ze zm.), dalej jako: pr. spółdz.

8 Ustawa z dnia 2 lipca 2004 r. o swobodzie działalności gospodarczej (t.j. Dz.U. z 2015 r., poz. 584).

9 Desygnaty zwrotu „ważne przyczyny” mieszczą się najczęściej w kategoriach objętych terminem „dobre obyczaje”. Przykładem może być uregulowanie przymusowego usunięcia członka z korporacji. Wyłączenie wspólnika ze spółki z ograniczoną odpowiedzialnością następuje bowiem z ważnych przyczyn (art. $266 \S 1$ k.s.h.), ale wykluczenie członka ze spółdzielni może mieć miejsce, gdy jego dalsze pozostawanie w spółdzielni nie da się pogodzić z postanowieniami statutu lub dobrymi obyczajami (art. 24 § 2 pr. spółdz.).

10 R. Stefanicki, Dobre obyczaje w prawie polskim, „Przegląd Prawa Handlowego” 2002, nr 5, s. 30 . 
go, i dobrych obyczajów. Można w tym zakresie wskazać klauzule przewidziane w przepisach kodeksu cywilnego, które na podstawie art. 2 k.s.h. stosuje się w sprawach dotyczących spółek handlowych, a nieuregulowanych w kodeksie spółek handlowych. Jeżeli wymaga tego natura (właściwość) stosunku prawnego spółki handlowej, przepisy te stosuje się odpowiednio. W szczególności do wykonywania praw przez wspólnika (a także spółkę) znajdzie zastosowanie art. 5 k.c. dotyczący konstrukcji nadużycia prawa podmiotowego, w której jednym z determinantów są zasady współżycia społecznego. Zakres obowiązku współdziałania wspólnika i spółki w wykonywaniu praw i obowiązków wynikających ze stosunku członkostwa należy oceniać przez pryzmat art. 354 k.c., a więc przy uwzględnieniu zasad współżycia społecznego i ustalonych zwyczajów. Z kolei klauzula dobrych obyczajów znajdzie - na ogólnych zasadach - zastosowanie przede wszystkim w stosunkach zewnętrznych: w związku z prowadzeniem negocjacji (art. $72 \S 2$ k.c.), zawarciem umowy w trybie aukcji lub przetargu (art. $70^{5}$ k.c.).

Poza tym można wyróżnić normy odwołujące się do dobrych obyczajów wynikające z przepisów należących do dziedziny prawa handlowego, a dotyczących spółek handlowych. Charakterystyczne jest przy tym, że regulacje te nie odwołują się do zasad współżycia społecznego, lecz właśnie do dobrych obyczajów. W prawie spółek handlowych przepisy posługiwały się tą klauzulą przez cały czas obowiązywania kodeksu handlowego ${ }^{11}$, a następnie została ona przejęta w kodeksie spółek handlowych. Zasadnicza różnica między tymi aktami prawnymi wyraża się w tym, że kodeks handlowy odwoływał się do dobrych obyczajów kupieckich, natomiast kodeks spółek handlowych stanowi o dobrych obyczajach. Zmiana taka może sugerować pewne rozszerzenie klauzuli w porównaniu z kodeksem handlowym ${ }^{12}$ przez odniesienie się do szerszego zakresu stosunków niż tylko gospodarcze ${ }^{13}$. Zarówno dobre obyczaje kupieckie w rozumieniu kodeksu handlowego, jak i dobre obyczaje według kodeksu spółek handlowych nie dotyczą jednak tylko stosunków między przedsiębiorcami (kupcami), ale również stosunków wewnętrznych przedsiębiorcy (kupca). W istocie więc odesłanie do dobrych obyczajów w kontekście stosunków spółki oznacza, że są to dobre obyczaje stosowane $\mathrm{w}$ stosunkach handlowych ${ }^{14}$ (wewnętrznych i zewnętrznych).

11 Rozporządzenie Prezydenta Rzeczypospolitej z dnia 27 czerwca 1934 r. - Kodeks handlowy (Dz.U., nr 57, poz. 502 ze zm.).

12 K. Strzelczyk, [w:] Kodeks spółek handlowych. Komentarz, red. T. Siemiątkowski, R. Potrzeszcz, t. 2, Warszawa 2011, s. 483; A. Koch, Podważanie uchwat zgromadzeń spótek kapitałowych, Warszawa 2011, s. 184; K. Kopaczyńska-Pieczniak, Spótka z ograniczona odpowiedzialnościa, Warszawa 2013, s. 731. Zob. też: S. Sołtysiński, [w:] System Prawa Prywatnego, t. 17B: Prawo spótek kapitałowych, red. S. Sołtysiński, Warszawa 2010, s. 600.

13 Wyrok SA w Katowicach z dnia 26 marca 2009 r., V ACa 49/09, OSA 2010, z. 7, s. 65, LEX nr 523888. Zob. również: S. Sołtysiński, Nieważne i wzruszalne uchwały zgromadzeń spółek kapitałowych, „Przegląd Prawa Handlowego” 2006, nr 1, s. 14.

14 A. Kidyba, Kodeks spótek handlowych. Komentarz, t. 1, Warszawa 2013, s. 1144; A. Szaj- 
W konsekwencji pojęcie to zdaje się mieć takie samo znaczenie na gruncie obu kodeksów ${ }^{15}$, czyli można je obecnie uzupełnić - w domyśle - określeniem ,gospodarcze”"16 lub „handlowe”.

\section{UJĘCIA DOBRYCH OBYCZAJÓW I ZASAD WSPÓŁŻYCIA SPOŁECZNEGO W PRAWIE HANDLOWYM}

W zakresie kryteriów, do których odsyła klauzula generalna zasad współżycia społecznego ${ }^{17} \mathrm{~W}$ doktrynie, można wyróżnić poglądy odwołujące się do: moralności ${ }^{18}$, moralności i obyczajowości ${ }^{19}$, reguł obyczajowych, organizacyjnych, powiązanych z pewną grupą norm moralnych ${ }^{20}$, uczciwości ${ }^{21}$, wartości wyrażonych $\mathrm{w}$ prawie pozytywnym ${ }^{22}$, szczególnych reguł postępowania $\mathrm{w}$ życiu społecznym, których nie można utożsamiać z normami prawnymi ani moralnymi ${ }^{23}$, słuszności i powszechnie uznawanych wartości w kulturze społeczeństwa ${ }^{24}$.

Jest to klauzula generalna odgrywająca dominującą rolę, gdyż ma najszersze zastosowanie i jest najczęściej powoływana w orzecznictwie ${ }^{25}$. Przez to, że zastąpiła poprzednio występujące klauzule, wskazuje się, że mieści w sobie jednocześnie treść dotąd odrębnych pojęć, jak dobra wiara, dobre obyczaje, a nawet po-

kowski, M. Tarska, [w:] S. Sołtysiński, A. Szajkowski, A. Szumański, J. Szwaja, Kodeks spółek handlowych. Komentarz, t. 2, Warszawa 2005, s. 707. Zob. też: J. Frąckowiak, [w:] Kodeks spótek handlowych. Komentarz, red. K. Kruczalak, Warszawa 2001, s. 683.

15 P. Grzesiok, Zaskarżanie uchwat w kodeksie spótek handlowych na tle rozwiąań kodeksu handlowego, „Prawo Spółek” 2002, nr 5, s. 7.

16 J. Szwaja, [w:] S. Sołtysiński, A. Szajkowski, A. Szumański, J. Szwaja, Kodeks spótek handlowych. Komentarz, t. 3, Warszawa 2008, s. 1249. Zob. wyrok SN z dnia 16 października 2008 r., III CSK 100/08, OSNC - ZD 2009, nr 1 (A), poz. 30.

17 M. Cetnarowicz (Zasady wspólżycia społecznego a dobre obyczaje, „Ius Novum” 2007, nr 2-3, s. 117) wskazuje, że historia tej klauzuli dowodzi zasadności twierdzenia, iż zasadniczy zwrot w jej pojmowaniu należy uznać za swoisty fenomen. Desygnat tego terminu na skutek przemian społeczno-gospodarczych uległ radykalnej zmianie, zachowując jednak literalne brzmienie.

18 Z. Radwański, M. Zieliński, op. cit., s. 395, 397.

19 A. Stelmachowski, Wstęp do teorii prawa cywilnego, Warszawa 1984, s. 152; idem, Zarys teorii prawa cywilnego, Warszawa 1998, s. 119.

20 A. Wolter, J. Ignatowicz, K. Stefaniuk, op. cit., s. 78.

${ }_{21}$ Zob. A. Żurawik, [w:] System Prawa Administracyjnego, t. 8A: Publiczne prawo gospodarcze, red. R. Hauser, Z. Niewiadomski, A. Wróbel, Warszawa 2013, s. 508.

22 R. Trzaskowski, Granice swobody ksztaltowania treści i celu umów obligacyjnych. Artykut $353^{l}$ K.C., Warszawa 2005, s. 394.

23 S. Grzybowski, [w:] System Prawa Cywilnego, t. 1: Część ogólna, red. S. Grzybowski, Wrocław 1974, s. 94.

24 Wyrok SN z dnia 6 października 1998 r., II CKN 291/98, „Rejent” 1999, nr 5, s. 104 i n.

25 A. Wolter, J. Ignatowicz, K. Stefaniuk, op. cit., s. 73. 
rządek publiczny ${ }^{26}$. Obecnie występuje jednak tendencja do zastępowania zasad współżycia społecznego innymi zwrotami niedookreślonymi, takimi jak „dobre obyczaje" lub ,względy słuszności"27.

$\mathrm{Z}$ kolei reprezentowane $\mathrm{w}$ doktrynie poglądy dotyczące istoty norm objętych klauzulą „dobre obyczaje”28 odwołują się do: moralności ${ }^{29}$, przyzwoitości czy uczciwości, godziwości (samodzielnie lub łącznie z moralnością) ${ }^{30}$, moralności i obyczajowości ${ }^{31}$, rzeczywiście panujących zwyczajów ${ }^{32}$, obyczajowości ${ }^{33}$, wyobrażeń funkcjonujących w społeczeństwie i jego poczucia prawnego ${ }^{34}$, sprawiedliwości ${ }^{35}$, etyki prawnej jako stanowiącej immanentny element panującego porządku społeczno-gospodarczego ${ }^{36}$, wartości konstytucyjnych, ocen zoriento-

26 A. Wolter, Z zagadnień powiązania nauki prawa z praktyka, „Państwo i Prawo” 1954, z. 2, s. 317; S. Grzybowski, Struktura i treść przepisów prawa cywilnego odsyłajacych do zasad wspótżycia społecznego, „Studia Cywilistyczne” 1965, t. 6, s. 65.

27 M. Safjan, Klauzule generalne w prawie cywilnym (przyczynek do dyskusji), „Państwo i Prawo" 1990, z. 11, s. 56; T. Zieliński, Klauzule generalne w nowym porzadku konstytucyjnym, „Państwo i Prawo” 1997, z. 11-12, s. 143-144; L. Leszczyński, Dobre obyczaje zamiast zasad wspólżycia społecznego, „Rzeczpospolita” 1998, nr 26, s. 17; T. Juszyński, Nadużycie prawa w polskim prawie cywilnym, Kraków 2000, s. 111 i n. Zob. rozważania Z. Radwańskiego i M. Zielińskiego (op. cit., s. 397-398). Por. też: B. Janiszewska, O potrzebie zmiany klauzuli zasad wspótżycia społecznego (głos w dyskusji), „Przegląd Ustawodawstwa Gospodarczego” 2003, nr 4, s. 7 i n.

28 Według Monteskiusza: „Kiedy naród ma dobre obyczaje, prawa stają się proste” (Monteskiusz, O duchu praw, przeł. T. Boy-Żeleński, Kęty 1997, s. 330 ).

29 R. Longchamps de Bérier, Zobowiązania, Poznań 1948, s. 157; F. Zoll, [w:] A. Krauss, F. Zoll, Polska ustawa o zwalczaniu nieuczciwej konkurencji, Poznań 1929, s. 170 i n.; J. Korzonek, I. Rosenblüth, Kodeks zobowiązań. Komentarz, Kraków 1934, s. 130; Z. Fenichel, Pojęcie „, dobrych obyczajów" w prawie polskim, Lwów 1934, s. 9; M. Allerhand, Kodeks handlowy. Komentarz, t. 2, Bielsko-Biała 1991, s. 92.

30 A. Krauss, F. Zoll, op. cit., s. 170-171; J. Korzonek, I. Rosenblüth, op. cit., s. 142; Z. Fenichel, op. cit., s. 23.

31 Z. Radwański, A. Olejniczak, Zobowiązania - część ogólna, Warszawa 2005, s. 156. Według Z. Fenichela (op. cit., s. 9) dobre obyczaje czasem są identyczne z moralnością, a czasem z obyczajami.

32 B. Gadek, Generalna klauzula odpowiedzialności za czyn nieuczciwej konkurencji (art. 3 u.z.n.k.), „Prace Instytutu Prawa Własności Intelektualnej Uniwersytetu Jagiellońskiego” 2003, nr 85, s. 129 i n.; C. Kosikowski, T. Ławicki, Ochrona prawna konkurencji i zwalczanie praktyk monopolistycznych, Warszawa 1994, s. 158-159.

33 B. Gadek, op. cit., s. 131; M. Pilich, Zasady wspótżycia społecznego, dobre obyczaje czy dobra wiara? Dylematy nowelizacji klauzul generalnych prawa cywilnego w perspektywie europejskiej, [w:] Europeizacja prawa prywatnego, red. M. Pazdan, W. Popiołek, E. Rott-Pietrzyk, M. Szpunar, Warszawa 2008, s. 172.

34 A. Szpunar, Nadużycie prawa podmiotowego, „Polska Akademia Umiejętności. Prace Komisji Prawniczej" 1947, nr 2, s. 64-65.

35 Przegląd tych koncepcji przedstawia A. Żurawik, Klauzula generalna ,dobrych obyczajów”-ujęcie teoretyczne, „Ruch Prawniczy, Ekonomiczny i Socjologiczny” 2009, nr 1, s. 35 i n.

36 R. Trzaskowski, op. cit., s. 114-115. M. Poźniak-Niedzielska (Kilka uwag o zachowaniu dobrych obyczajów w działalności gospodarczej, [w:] Iustitia civitatis fundamentum. Księga pa- 
wanych na zapewnienie niezakłóconego funkcjonowania konkurencji, gospodarki czy obrotu gospodarczego (ujęcie ekonomiczno-funkcjonalne) ${ }^{37}$, chrześcijańskiego systemu wartości ${ }^{38}$. Warto zwrócić uwagę na pogląd, zgodnie z którym istotą pojęcia dobrego obyczaju jest szeroko rozumiany szacunek dla drugiego człowie$\mathrm{ka}^{39}$. W każdym przypadku dobre obyczaje powinny się wyrażać w szacunku dla partnera, uczciwości, rzetelności, zaufaniu, lojalności, szczerości, fachowości ${ }^{40}$, poszanowaniu godności, niewprowadzaniu w błąd.

W prawie spółek handlowych klauzule zasad współżycia społecznego i dobrych obyczajów są ujmowane w zróżnicowany sposób. W szczególności dobre obyczaje są rozumiane jako normy pozaprawne, obyczajowe, które wyznaczają standardy uczciwego i zgodnego z zasadami racjonalnej gospodarki zachowania w działalności i funkcjonowaniu korporacji, które mogą dotyczyć stosunków wewnętrznych spółki (ładu korporacyjnego), a także jej stosunków zewnętrznych. Obejmują wszelkie normy uczciwego postępowania, które mogą mieć zastosowanie w stosunkach spółki ${ }^{41}$. Ujmuje się je jako odsyłające do pozaprawnych, powszechnie akceptowanych reguł postępowania, które mają raczej charakter obiektywny, społeczny ${ }^{42}$. Wskazuje się też, że jest to zespół norm wynikają-

miątkowa ku czci Profesora Wiesława Chrzanowskiego, red. H. Cioch, ks. A. Dębiński, J. Chaciński, Lublin 2003, s. 176) uznaje dobre obyczaje za normy etyczne i zwyczajowe.

37 J. Szwaja, [w:] Ustawa o zwalczaniu nieuczciwej konkurencji. Komentarz, red. J. Szwaja, Warszawa 2006, s. 159-160. Nawet w ujęciu ekonomiczno-funkcjonalnym dobre obyczaje są jednak ujmowane jako normy moralne i zwyczajowe stosowane w działalności gospodarczej (uzasadnienie wyroku SN z dnia 26 września 2002 r., III CKN 213/01, OSN 2003, nr 12, poz. 169) czy też jako normy moralne i obyczajowe w stosunkach gospodarczych, tzw. uczciwość kupiecka (wyrok SA w Katowicach z dnia 28 czerwca 2007 r., V ACa 371/07, niepubl.). Z kolei J. Preussner-Zamorska (Problematyka klauzul generalnych na gruncie ustawy o zwalczaniu nieuczciwej konkurencji. Klauzula dobrych obyczajów w art. 16, „Kwartalnik Prawa Prywatnego” 1998, nr 4, s. 657) podkreśla potrzebę ocen moralno-etycznych przy zastosowaniu ujęcia ekonomiczno-funkcjonalnego dobrych obyczajów.

38 S. Rudnicki, Reklama sprzeczna z dobrymi obyczajami lub uchybiająca godności człowie$k a$, ,Monitor Prawniczy” 1996, nr 1, s. 5; A. Żurawik, Dobre obyczaje a zwyczaje, zasady wspótżycia społecznego i dobra wiara - ujęcie teoretyczne, „Kwartalnik Prawa Publicznego” 2007, nr 4, s. 201. Odmiennie: M. Pilich, op. cit., s. 172.

39 Por. wyrok SA w Gdańsku z dnia 6 listopada 1996 r., I ACr 839/96, PG 1997, nr 6, s. 38, OSA 1997, nr 10, poz. 57; wyrok SOKiK z dnia 23 lutego 2006 r., XVII Ama 118/04, Dz.Urz. UOKiK 2006, nr 2, poz. 31.

40 A. Olejniczak ([w:] Kodeks cywilny. Komentarz, t. 3: Zobowiązania. Część ogólna, red. A. Kidyba, Warszawa 2010, s. 222) odnosi te wartości do dobrych obyczajów w stosunkach z konsumentami.

${ }^{41}$ K. Kopaczyńska-Pieczniak, op. cit., s. 730-731; J. Szwaja, [w:] Ustawa..., s. 154 i n.; A. Koch, op. cit., s. 184 i n.; D. Wajda, Dobre obyczaje w spótkach kapitałowych, [w:] Prawo handlowe XXI wieku. Czas stabilizacji, ewolucji czy rewolucji. Księga jubileuszowa Profesora Józefa Okolskiego, red. M. Modrzejewska, Warszawa 2010, s. 1194 i n.

42 U. Promińska, $W$ sprawie relacji pomiędzy art. 3 a art. 16 ust. 1 pkt 1 u.z.n.k., [w:] Reklama. Aspekty prawne, red. M. Namysłowska, Warszawa 2012, s. 110. 
cych ze stworzenia abstrakcyjnego modelu uczciwego i efektywnego inwestora i przedsiębiorcy, który znajduje uzasadnienie w regułach prawidłowej gospodarki i wartościach etycznych ${ }^{43}$. Dobre obyczaje należy wiązać z tzw. zasadami uczciwego obrotu, co wiąże się z podwyższonym standardem wymagań stawianych uczestnikom obrotu gospodarczego ${ }^{44}$.

W wypowiedziach doktryny często utożsamia się dobre obyczaje z normami moralnymi dotyczącymi postępowania jednych ludzi wobec drugich ${ }^{45}$. Niejednokrotnie wskazuje się też na potrzebę uwzględnienia dodatkowych kryteriów o obiektywnym charakterze, w szczególności: kryteriów ekonomiczno-funkcjonalnych i ocen zorientowanych na zapewnienie niezakłóconego funkcjonowania spółki ${ }^{46}$, reguł efektywności, o ile są oparte na wartościach etycznych, reguł organizacyjnych, obyczajowych, które służą osiągnięciu porządku, sprawności, efektywności, zachowaniu tradycji, ale nie muszą mieć konotacji moralnej (bez której nie mogą być zaliczone do zasad współżycia społecznego ${ }^{47}$. Proponuje się również połączenie takich wartości i odesłanie do powszechnie aprobowanych w obrocie wartości moralno-ekonomicznych ${ }^{48}$, a także potrzebę wykorzystywania kryteriów ekonomiczno-moralnych ${ }^{49}$. Inne ujęcie zakłada, że klauzula dobrych obyczajów jest oparta na kryterium ocennym zaczerpniętym z zasad powszechnej obyczajowości. Przez dobre obyczaje należy rozumieć takie zachowania, które pozytywnie wpływają na funkcjonowanie spółki i otoczenie ,gospodarcze”, związane z przestrzeganiem uczciwości „kupieckiej” przy prowadzeniu działalności gospodarczej ${ }^{50}$. Wskazuje się też, że dobre obyczaje wyznaczają przyzwoite postępowanie, które uwzględnia w odpowiednim stopniu różne interesy służące wszystkim w spółce ${ }^{51}$.

Z kolei odnośnie do zasad współżycia społecznego przyjmuje się odwołanie do powszechnie uznanych w kulturze społeczeństwa wartości, które są zarazem

${ }_{43}$ M. Spyra, [w:] System Prawa Handlowego, t. 2B: Prawo spótek handlowych, red. S. Włodyka, Warszawa 2007, s. 497.

44 T. Szczurowski, Wadliwość czynności prawnych spótek kapitałowych na tle sankcji kodeksu cywilnego, Warszawa 2012, s. 256.

45 Ł. Gasiński, Granice swobody kształtowania treści statutu spółki akcyjnej, Warszawa 2014, s. 226; M. Pyziak-Szafnicka, [w:] System Prawa Prywatnego..., t. 1, s. 907; P. Machnikowski, Swoboda umów wedtug art. $353^{l}$ KC. Konstrukcja prawna, Warszawa 2005, s. 258 i n.; R. Trzaskowski, op. cit., s. 395 i n.

${ }^{46}$ R. Stefanicki, op. cit., s. 30-31; J. Szwaja, [w:] S. Sołtysiński, A. Szajkowski, A. Szumański, J. Szwaja, op. cit., t. 3, s. 1250.

47 M. Pyziak-Szafnicka, op. cit., s. 906-907.

48 P. Popardowski, Organy spótek kapitałowych i ich członkowie w najnowszym orzecznictwie Sądu Najwyższego, „Glosa” 2014, nr 1, s. 7.

49 J. Szwaja, [w:] S. Sołtysiński, A. Szajkowski, A. Szumański, J. Szwaja, op. cit., t. 3, s. 1250.

50 Idem, [w:] S. Sołtysiński, A. Szajkowski, J. Szwaja, Kodeks handlowy. Komentarz, t. 2, Warszawa 1998, s. 829. Zob. również: D. Wajda, op. cit., s. 1194 i n. Zob. szerzej: A. Koch, op. cit., s. 184 i n.; T. Szczurowski, op. cit., s. 245 i n.

51 Zob. wyrok SA w Warszawie z dnia 10 maja 2013 r., VI ACa 157/12, LEX nr 1342422. 
dziedzictwem i składnikiem kultury europejskiej ${ }^{52}$. Są one interpretowane jako obejmujące odesłanie do reguł moralnych oraz prakseologicznych reguł związanych z wykonywaniem uprawnień organizacyjnych, co zakłada ocenę nie tylko z punktu widzenia dobra i zła, ale także reguł organizacyjnych pozwalających na dokonanie ocen funkcjonalno-ekonomicznych ${ }^{53}$.

W orzecznictwie można wskazać poglądy nawiązujące do norm moralnych, godziwości ${ }^{54}$, uczciwości kupieckiej, norm przyzwoitego zachowania ${ }^{55}$. Występują też odwołania do kryteriów ekonomicznych, funkcjonalnych, zwyczajów $^{56}$. Stanowisko pośrednie wyraża się w nawiązaniu do norm etycznych, uczciwości kupieckiej, uwzględniającej jednak kryteria ekonomiczno-funkcjonalne i oceny zorientowane na zapewnienie niezakłóconego funkcjonowania i rozwoju spółki kapitałowej, a także poszanowanie interesów jej wspólników i akcjonariuszy ${ }^{57}$.

Poza tym w świetle orzecznictwa pojawiło się zagadnienie zakwalifikowania pewnej stałej praktyki w spółce za obyczaj (dobry obyczaj) czy też za pewien zwyczaj - „korporacyjny uzus" ${ }^{58}$. Inspiracją był pogląd zakładający indywidualizację oceny dobrych obyczajów przez uznanie, że są one ukształtowane przez praktykę wewnątrzkorporacyjną danej spółki ${ }^{59}$. Takie ujęcie stanowi odstępstwo od rozumienia tej klauzuli jako klauzuli generalnej, której treść wypełniają powszechnie aprobowane w obrocie wartości, i od utrwalonego sposobu interpretacji „dobrych obyczajów” jako mających charakter uniwersalny reguł postępowania $\mathrm{w}$ obrocie ${ }^{60}$.

52 Z. Radwański, M. Zieliński, op. cit., s. 397.

53 S. Sołtysiński, [w:] System Prawa Prywatnego..., t. 17B, s. 601; A. Wolter, J. Ignatowicz, K. Stefaniuk, op. cit., s. 78.

${ }^{54}$ Wyrok SN z dnia 20 czerwca 2001 r., I CKN 1137/98, OSNC 2002, nr 3, poz. 31; wyrok SN z dnia 6 marca 2009 r., II CSK 522/08, LEX nr 494003.

55 Wyrok SA w Katowicach z dnia 26 marca 2009 r., V ACa 49/09, LEX nr 523888; wyrok SA w Poznaniu z dnia 1 kwietnia 2014 r., I ACa 91/14, LEX nr 1493794; wyrok SA w Gdańsku z dnia 29 maja 2014 r., I ACa 135/14, LEX nr 1504359.

56 Wyrok SN z dnia 16 października 2008 r., III CSK 100/08, OSNC - ZD 2009, nr 1 (A), poz. 30; wyrok SA w Katowicach z dnia 23 listopada 2006 r., I ACa 1373/06, LEX nr 307269; wyrok SA w Krakowie z dnia 15 listopada 2012 r., I ACa 1036/12, LEX nr 1236699.

57 Wyrok SN z dnia 27 marca 2013 r., I CSK 407/12, OSP 2013, nr 11, poz. 108; wyrok SN z dnia 8 marca 2005 r., IV CK 607/04, LEX nr 289387.

58 A. Stokłosa, Glosa do wyroku SN z dnia 27 marca 2013 r., I CSK 407/12, „Przegląd Sądowy" 2014, nr 10, s. 134.

59 Zob. wyrok SN z dnia 27 marca 2013 r., I CSK 407/12, OSP 2013, z. 11, s. 792 i n., według którego dobre obyczaje w rozumieniu art. 422 k.s.h. mogą wykształcić się w wyniku istnienia określonej praktyki korporacyjnej w pojedynczej spółce.

60 P. Popardowski, op. cit., s. 7. Zob. również: A. Opalski, Glosa do wyroku SN z dnia 27 marca 2013 r., I CSK 407/12, „Orzecznictwo Sądów Polskich” 2013, z. 11, s. 797 i n.; A. Stokłosa, Zaskarżanie uchwat zgromadzeń spółek kapitałowych. Glosa do wyroku Sądu Najwyższego z 27 marca 2013 r., I CSK407/12, „Przegląd Sądowy” 2014, nr 10, s. 134 i n. 
Istotnym zagadnieniem jest również wybór koncepcji postrzegania zasad współżycia społecznego czy dobrych obyczajów: normatywnej (obiektywnej) lub sytuacjonistycznej (subiektywnej). Poprzeć w tym zakresie należy stanowisko pośrednie, zakładające krytykę pełnej obiektywizacji tych norm, jednocześnie jednak przestrzegające przed skrajnie subiektywistycznym podejściem $^{61}$. Ocena sprzeczności czy zgodności z dobrymi obyczajami powinna uwzględniać całokształt okoliczności, zwłaszcza cel, użyte środki i konsekwencje podjętych działań ${ }^{62}$. Wymaga ona uwzględnienia interesu spółki, interesów wspólników ze względu na cele wynikające z umownego współżycia $^{63}$, a także dokonania szeregu wartościowań, w tym rozstrzygnięcia konfliktu między różnymi zasadami ${ }^{64}$.

Specyficzna dla obrotu gospodarczego jest też tendencja do katalogowania dobrych obyczajów w postaci kodeksów etycznych lub dobrych praktyk dotyczących po prostu działalności gospodarczej, poszczególnych grup zawodowych lub rodzajów działalności, np. różne branżowe zasady ładu korporacyjnego ustalane przez zrzeszenia grup podmiotów, izby gospodarcze i organy giełd (tzw. dobre praktyki) ${ }^{65}$. Pełnią one rolę pomocniczą, nie zawierają (bo nie mogą) zamkniętego katalogu takich zasad, a przy tym nie zawsze zawarte tam reguły $\mathrm{w}$ istocie odpowiadają dobrym obyczajom, wyrażając raczej interesy danej grupy przedsiębiorców ${ }^{66}$. Normy zawarte $w$ tych kodeksach, jako podstawa oceny uczciwego zachowania, powinny uprzednio zostać skontrolowane przez pryzmat założeń ogólnej uczciwości ${ }^{67}$.

${ }_{61}$ M. Safjan, op. cit., s. 54; M. Pyziak-Szafnicka, op. cit., s. 909; R. Trzaskowski, op. cit., s. 406 i n.; Ł. Gasiński, op. cit., s. 228. Na temat wskazanych koncepcji zob. też: T. Bukowski, Klauzule generalne w prawie cywilnym. O konieczności stworzenia katalogu zasad wspólżycia społecznego, „Monitor Prawniczy” 2008, nr 24, s. 1300 i n.; W. Dajczak, Zasady współżycia społecznego czy dobra wiara?, „Rejent” 2001, nr 1, s. 52 i n.

62 T. Szczurowski, op. cit., s. 255.

63 T. Dziurzyński, Z. Fenichel, M. Honzatko, Kodeks handlowy. Komentarz, Łódź 1992, s. 266. Zob. też: A. Rachwał, [w:] System Prawa Handlowego, t. 2A: Prawo spótek handlowych, red. S. Włodyka, Warszawa 2007, s. 1002.

${ }_{64}$ R. Trzaskowski, op. cit., s. 406 i n.

${ }_{65} \mathrm{Na}$ temat Dobrych Praktyk Spółek Notowanych na Giełdzie Papierów Wartościowych zob. A. Kidyba, Kodeks spótek handlowych. Komentarz, t. 2, Warszawa 2013, s. 771 i n.

${ }_{66}$ Zob. E. Nowińska, M. du Vall, Komentarz do ustawy o zwalczaniu nieuczciwej konkurencji, Warszawa 2006, s. 34. Zob. też: R. Biskup, Dobre obyczaje w działalności gospodarczej, „Annales: Etyka w Życiu Gospodarczym” 2007, nr 1, s. 156.

${ }^{67}$ Ustawodawca uznał za nieuczciwą praktykę rynkową stosowanie kodeksu dobrych praktyk, którego postanowienia są sprzeczne z prawem art. 11 ust. 1 u.n.p.r. Wydaje się, że tak samo należy oceniać stosowanie takiego kodeksu, którego postanowienia naruszają dobre obyczaje czy zasady współżycia społecznego. 


\section{„ZBIEG” KLAUZUL GENERALNYCH - „ZASADY WSPÓŁŻYCIA SPOŁECZNEGO” I „DOBRE OBYCZAJE” W STOSUNKACH SPÓŁEK HANDLOWYCH}

Specyficzny zbieg (konkurencja) klauzul generalnych zasad współżycia społecznego i dobrych obyczajów w stosunkach spółek handlowych występuje w przypadkach, gdy ten sam ich aspekt podlega ocenie w różnych spółkach przy wykorzystaniu jednej lub drugiej klauzuli. Stanowi to konsekwencję posługiwania się przez kodeks cywilny przede wszystkim klauzulą zasad współżycia społecznego, a kodeks spółek handlowych - klauzulą dobrych obyczajów oraz ujęcia wzajemnej relacji tych kodeksów jako lex generalis - lex specialis (art. 2 k.s.h.). Taka konkurencja obu klauzul jest widoczna przede wszystkim w dwóch płaszczyznach: oceny zakresu swobody umów przy kształtowaniu umowy spółki handlowej (art. 3 k.s.h.) oraz zaskarżania uchwał zgromadzeń w spółkach kapitałowych.

Klauzula dobrych obyczajów znajduje zastosowanie w aspekcie oceny dopuszczalności zawarcia określonych postanowień w statucie spółki akcyjnej (art. $304 \S 4$ k.s.h.). Można też uznać, że art. $304 \S 4$ k.s.h. ma odpowiednie zastosowanie do statutu spółki komandytowo-akcyjnej (art. 126 § 1 pkt 2 k.s.h.), jednak wydaje się, że w tym przypadku nie ma potrzeby odesłania do przepisów o spółce akcyjnej z uwagi na treść art. 130 k.s.h. Można też uznać, że art. 304 k.s.h. ma odpowiednie zastosowanie tylko w zakresie wyznaczonym przez art. $126 \S 1$ pkt 2 k.s.h., zaś w pozostałym zakresie swobodę umów kształtuje art. $353^{1}$ k.c. w zw. art. 2 k.s.h. ${ }^{68} \mathrm{~W}$ przypadku pozostałych spółek handlowych granice swobody kształtowania treści umowy (statutu) wyznaczają stosownie do art. $353^{1}$ k.c. w zw. z art. 2 k.s.h. zasady współżycia społecznego ${ }^{69}$. Wprawdzie proponuje się zastosowanie do spółki z ograniczoną odpowiedzialnością per analogiam art. 304 $\S 4$ k.s.h..$^{70}$, lecz nie wydaje się, by taka analogia z uwagi na naturę obu spółek była uzasadniona $^{71}$. Warto przy tym zaznaczyć, że na tle art. $304 \S 4$ k.s.h. wskazuje się na możliwość zastosowania również klauzuli zasad współżycia społecznego (art.

${ }^{68} \mathrm{Na}$ temat statutu spółki komandytowo-akcyjnej zob. T. Bieniek, Utworzenie spółki komandytowo-akcyjnej, „Prawo Spółek” 2001, nr 123, s. 14 i n.; D. Sokołowska, Statut spółki komandytowo-akcyjnej, [w:] Prawo handlowe po przystapieniu Polski do Unii Europejskiej, red. W.J. Katner, U. Promińska, Warszawa 2010, s. 275 i n.

${ }^{69}$ Tak między innymi: A. Kidyba, Kodeks..., t. 1, s. 33; S. Sołtysiński, [w:] System Prawa Prywatnego..., t. 17B, s. 16-17; S. Włodyka, [w:] System Prawa Handlowego ..., t. 2A, s. 47; W. Pyzioł, [w:] Kodeks spółek handlowych. Komentarz, red. W. Pyzioł, Warszawa 2008, s. 332. Zob. też: M. Tarska, Zakres swobody umów w spótkach handlowych, Warszawa 2012, s. 94.

70 A. Rachwał, op. cit., s. 888.

71 Odmiennie R.L. Kwaśnicki (Autonomia woli w kształtowaniu postanowień umowy (aktu założycielskiego) spółki z o.o., „Prawo Spółek” 2003, nr 7-8, s. 19), który proponuje stosowanie do tej umowy art. 304 § 3-4 k.s.h. z uwagi na to, że nie ma ona charakteru tylko kontraktowego. 
$353^{1}$ k.c. w zw. z art. 2 k.s.h.) ze względu na to, że art. 304 k.s.h. nie wyczerpuje zagadnień związanych z granicami swobody kształtowania treści statutu ${ }^{72}$.

Zasadniczy problem dotyczy jednak zakwalifikowania zasad współżycia społecznego jako podstawy zaskarżenia uchwały wspólników czy walnego zgromadzenia w spółkach kapitałowych. Wynika on z tego, że zgodnie z art. $249 \S 1$ i art. $422 \S 1$ k.s.h. podstawą żądania uchylenia uchwały jest jej sprzeczność z dobrymi obyczajami, o ile jednocześnie godzi w interesy spółki lub ma na celu pokrzywdzenie wspólnika.

Na marginesie można zwrócić uwagę, że w zasadzie zarówno uchwała, która godzi w interesy spółki, jak i taka, która ma na celu pokrzywdzenie wspólnika już przez to może być uznana za sprzeczną z dobrymi obyczajami, co wynika z natury spółki jako struktury, w ramach której istnieje zobowiązanie do dążenia do wspólnego celu. Istota tego współdziałania polega na tym, że powinny to być działania korzystne dla wszystkich wspólników i dla spółki. W związku z tym sprzeczne z dobrymi obyczajami są takie zachowania, które godzą w interesy tej korporacji lub zmierzają do pokrzywdzenia niektórych jej członków. Dobre obyczaje w stosunkach korporacyjnych przejawiają się między innymi w uczciwym współdziałaniu, zgodnym z istotą korporacji jako organizacji zrzeszającej pewną grupę osób dla wspólnego celu. Powinno je cechować poszanowanie interesów spółki i pozostałych jej członków. Przy tym uchwała sprzeczna z interesami spółki może być przykładem specyficznego paradoksu aksjologicznego, gdyż - zgodnie z teorią organów (art. 38 k.c.) - uchwała kreuje wolę spółki, w związku z tym podjęcie takiej uchwały stanowi w istocie przejaw pewnej autodestrukcji.

Z kolei podstawą nieważności uchwały jest jej sprzeczność z ustawą (art. 252 $\S 1$, art. 425 § 1 k.s.h.). Tymczasem zgodnie z art. 58 § 1 i 2 k.c. nieważnością bezwzględną dotknięta jest czynność prawna sprzeczna z prawem lub zasadami współżycia społecznego. Pomijając w tym miejscu spór dotyczący charakteru prawnego uchwał, należy przyjąć, że są to czynności prawne. W związku z tym powstaje problem zakwalifikowania uchwały sprzecznej z zasadami współżycia społecznego jako podlegającej uchyleniu, czyli dotkniętej nieważnością względną, czy też jako nieważnej, podlegającej powództwu o stwierdzenie nieważności ${ }^{73}$. Ma to znacze-

72 S. Sołtysiński, [w:] S. Sołtysiński, A. Szajkowski, A. Szumański, J. Szwaja, op. cit., t. 3, s. 93; M. Tarska, op. cit., s. 127.

73 Problem ten podniósł Sąd Apelacyjny w Katowicach w pytaniu prawnym do Sądu Najwyższego, dotyczącym następującego problemu: „[...] czy naruszenie zasad współżycia społecznego uchwałą zgromadzenia wspólników spółki z o.o. może być wzięte pod uwagę tylko w ramach szczególnej klauzuli generalnej »dobrych obyczajów « i w związku z tym może stanowić podstawę uchylenia takiej uchwały, jeżeli jednocześnie godzi ona w interesy spółki lub ma na celu pokrzywdzenie wspólnika w przypadku wytoczenia powództwa o jej uchylenie przeciwko spółce (art. 249 $\S 1$ k.s.h.), czy też uchwałą bezwzględnie nieważną (art. $58 \S 2$ k.c.), a przeciwko spółce można wytoczyć powództwo o stwierdzenie jej nieważności (art. $252 \S 1$ k.s.h.)”. 
nie ze względu na rozbieżność ocen zachowania naruszającego wskazane klauzule. Sprzeczność z zasadami współżycia społecznego ma w świetle art. 58 k.c. porównywalną doniosłość z aktami naruszenia prawa. Naruszenie dobrych obyczajów według art. 249 i art. 422 k.s.h. nie stanowi natomiast samodzielnej przesłanki uzasadniającej zaistnienie sankcji cywilnoprawnej, lecz wymagane jest jednoczesne istnienie kolejnej przesłanki w postaci godzenia w interesy spółki lub w celu pokrzywdzenia wspólnika. Ponadto ich stwierdzenie stanowi podstawę żądania uchylenia uchwały, czyli zastosowania sankcji nieważności względnej.

Przedstawione zagadnienie dotyczy w istocie dwóch kwestii: stosunku dobrych obyczajów do zasad współżycia społecznego oraz stosunku przepisów kodeksu spółek handlowych do kodeksu cywilnego w zakresie sankcji wadliwych czynności prawnych, czyli dopuszczenia możliwości stosowania ogólnych przepisów o sankcjach czynności prawnych, zawartych w k.c., do uchwał zgromadzeń spółek kapitałowych.

\section{STOSUNEK DOBRYCH OBYCZAJÓW DO ZASAD WSPÓŁŻYCIA SPOŁECZNEGO}

Na gruncie przepisów kodeksu spółek handlowych stosunek klauzuli „dobre obyczaje” do „zasad współżycia społecznego” jest ujmowany w zróżnicowany sposób:

- $\quad$ są to pojęcia tożsame, ich zakresy się pokrywają ${ }^{74}$,

- „dobre obyczaje” wchodzą w zakres pojęcia „zasady współżycia społecznego"75, ,dobre obyczaje" to część składowa „zasad współżycia społecznego"76, czyli „zasady współżycia społecznego” to pojęcie szersze niż „dobre obyczaje”,

- pojęcia te nie są synonimami, choć ich zakresy w znacznym stopniu się pokrywają, co jest ujmowane jako stosunek krzyżowania się tych pojęć ${ }^{77}$,

- zakresy obu pojęć są rozłączne, co oznacza rozróżnienie uchwał sprzecznych z dobrymi obyczajami i uchwał niezgodnych z zasadami współżycia społecznego; „,dobre obyczaje” nie powinny być utożsamiane z „zasadami współżycia społecznego", skoro ustawodawca wprowadza oba te pojęcia ${ }^{78}$.

74 Wyrok SN z dnia 25 lutego 2010 r., I CSK 384/09, OSNC 2010, nr 10, poz. 140; podobnie uchwała SN z dnia 20 grudnia 2012 r., III CZP 84/12, OSNC 2013, nr 7-8, poz. 83. Zob. też: S. Sołtysiński, [w:] S. Sołtysiński, A. Szajkowski, A. Szumański, J. Szwaja, op. cit., t. 3, s. 93; J. Szwaja, [w:] S. Sołtysiński, A. Szajkowski, A. Szumański, J. Szwaja, op. cit., t. 3, s. 40.

75 K. Kruczalak, Prawo handlowe. Zarys wykładu, Warszawa 1997, s. 168.

76 T. Knypl, K. Trzciński (Znaczenie zwyczajów i dobrych obyczajów w prawie cywilnym $i$ handlowym, „Przegląd Prawa Handlowego” 1997, nr 8, s. 22) twierdzą jednocześnie, że dobre obyczaje należy rozumieć podobnie do zasad współżycia społecznego.

77 S. Sołtysiński, [w:] System Prawa Prywatnego..., t. 17B, s. 600. Zob. też: M. Kępiński, Problemy ogólne nowej ustawy o zwalczaniu nieuczciwej konkurencji, „Ruch Prawniczy, Ekonomiczny i Socjologiczny" 1994, nr 2, s. 7.

78 Zob. np.: T. Knypl, R. Trzciński, op. cit., s. 19 i n. 
Na tle dopuszczalnych dróg podważenia uchwał naruszających wskazane normy pozaprawne przyjęcie określonego poglądu rodzi istotne konsekwencje. Uznanie pokrywania się obu pojęć powoduje, że uchwała naruszająca zasady współżycia społecznego powinna być traktowana na gruncie k.s.h. jako sprzeczna z dobrymi obyczajami i zaskarżana na podstawie art. $249 \S 1$ i art. $422 \S 1$ k.s.h. w drodze powództwa o uchylenie uchwały (o ile są spełnione dalsze przesłanki). W pozostałych przypadkach pojawia się pytanie o dopuszczalność zaskarżenia uchwały, która jest sprzeczna z zasadami współżycia społecznego, ale jednocześnie nie wypełnia przesłanki naruszenia dobrych obyczajów, czy też generalnie o możliwość podważenia uchwał sprzecznych z zasadami współżycia społecznego. Wyznaczenie wzajemnego stosunku tych dwóch klauzul ma więc doniosłe znaczenie praktyczne, gdyż wpływa na ocenę dopuszczalności zaskarżenia uchwały, a także charakteru powództwa i skutku wyroku uwzględniającego powództwo.

Reprezentowane w doktrynie poglądy, zakładające brak tożsamości między zasadami współżycia społecznego a dobrymi obyczajami, niejednolicie ujmują różnice między tymi dwiema kategoriami norm. W szczególności wskazuje się, że:

- dobre obyczaje są normami równorzędnymi do zasad współżycia społecznego, przy czym zasady współżycia społecznego odwołują się do zasad właściwych społeczeństwu, a dobre obyczaje można odnosić do postępowania jednostki w określonej dziedzinie ${ }^{79}$,

- w przypadku zasad współżycia społecznego większą rolę odgrywa pierwiastek społeczny, natomiast dobre obyczaje koncentrują się przede wszystkim na kryterium przyzwoitości,

- zasady współżycia społecznego odsyłają do norm moralnych ${ }^{80}$, a dobre obyczaje - do norm obyczajowych ${ }^{81}$,

- zasady współżycia społecznego to normy moralne określające idealny, modelowy wzór zachowania się w danych okolicznościach, niezależnie od tego, czy jest rzeczywiście praktykowany, ale jest powszechnie uznany, natomiast dobre obyczaje to normy, których istotnym czynnikiem warunkującym ich istnienie jest rzeczywista, powtarzalna praktyka postępowania ${ }^{82}$,

79 M.A. Waligórski, [w:] System Prawa Handlowego, t. 1: Prawo handlowe - część ogólna, red. S. Włodyka, Warszawa 2009, s. 522; M. Cetnarowicz, op. cit., s. 124; A. Laszczyk, M. Gajdus, Wedle dobrych obyczajów czy zgodnie z zasadami wspólżycia społecznego? Uwagi na tle funkcjonowania klauzuli generalnej z Ustawy o zwalczaniu nieuczciwej konkurencji, „Przegląd Prawniczy Uniwersytetu im. Adama Mickiewicza" 2012, nr 1, s. 33.

${ }^{80} \mathrm{Na}$ temat rozumienia pojęcia „moralność” zob. P. Machnikowski, op. cit., s. 265; R. Trzaskowski, op. cit., s. 413; Z. Ziembiński, Wstęp do aksjologii dla prawników, Warszawa 1990, s. 231.

81 Na temat różnic między normami moralnymi a normami obyczajowymi zob. M. Cetnarowicz, op. cit., s. 120. Zob. też: Z. Ziembiński, Etyczne problemy prawoznawstwa, Wrocław 1972, s. 89 i n.

82 P. Machnikowski, op. cit., s. 264; A. Żurawik, Dobre obyczaje a zwyczaje ..., s. 208. Na konieczność wartościowania z punktu widzenia dobra i słuszności zwracają uwagę: R. Trzaskowski, op. cit., s. 412; Z. Radwański, M. Zieliński, op. cit., s. 395. 
- klauzula dobrych obyczajów jest zorientowana na wyznaczenie wzorca właściwego postępowania w ramach konkretnego stosunku cywilnoprawnego, nie odnosząc się do społecznego wymiaru i społecznych skutków określonego zachowania ${ }^{83}$.

Wydaje się, że aby ustalić stosunek zakresów obu klauzul, należy uwzględnić następujące okoliczności. Przede wszystkim porównanie nie może opierać się tylko na wykładni językowej, która nie powinna decydować o zakresie treściowym klauzuli generalnej. Oba terminy: „zasady współżycia społecznego” oraz „,dobre obyczaje" - należy z punktu językowego traktować jako związki frazeologiczne. Opierając się na dosłownym brzmieniu tych pojęć, konieczne jest natomiast ustalenie relacji między określeniami „współżycie społeczne” a „obyczaje”, co w istocie prowadzi do wniosku, że w obu przypadkach są to normy dotyczące postępowania $\mathrm{w}$ stosunkach międzyludzkich. Poza tym wprawdzie racjonalny ustawodawca powinien dla tego samego pojęcia używać tego samego terminu, lecz w przypadku klauzul generalnych, z uwagi na ich niedookreśloność, nie zawsze to założenie było i jest realizowane ${ }^{84}$. Zaistnienie sytuacji obowiązywania obu wskazanych klauzul generalnych zostało spowodowane specyficzną sytuacją związaną z przemianami społeczno-politycznymi, a co za tym idzie - zmianami w ustawodawstwie. Odmienne nazwy nie mogą przekreślać możliwości ich utożsamienia. Wreszcie określenie wzajemnego stosunku ich zakresów jest możliwe przy uwzględnieniu tych samych kryteriów, desygnatów, skoro w obu przypadkach są one ujmowane analogicznie.

W związku z powyższym wydaje się, że między obiema klauzulami zachodzą bardzo istotne podobieństwa. Przede wszystkim obie klauzule są trudne do jednoznacznego określenia - ich zakresy są bardzo pojemne i elastyczne, więc nie jest możliwe ich precyzyjne zdefiniowanie i skatalogowanie. Poza tym odwołują się do pozaprawnej sfery stosunków społecznych i wymagają oceny określonego zdarzenia $\mathrm{w}$ świetle takiego aspektu relacji międzyludzkich, który nie podlega regulacji prawnej.

Sformułowanie ich nazw może być odczytywane jako sugerujące różnicę w zakwalifikowaniu z punktu widzenia wartościowania, gdyż można stwierdzić, że zasady współżycia społecznego to klauzula o postaci normatywnej, natomiast dobre obyczaje stanowią klauzulę wartościującą. Wydaje się jednak, że zbyt duże znaczenie przywiązuje się wskazaniu, że obyczaje mają być „dobre”, skoro jednocześnie zasady współżycia społecznego traktuje się właśnie tylko jako dobre zasady, choć brak jest w tym przypadku takiego wyraźnego wartościowania. Tymczasem można przyjąć, że pojęcie zasad współżycia społecznego, tak jak obyczajów,

83 B. Janiszewska, Klauzula generalna dobrych obyczajów $w$ znowelizowanych przepisach kodeksu cywilnego, „Przegląd Prawa Handlowego” 2003, nr 10, s. 16-17.

84 Zob. T. Justyński, op. cit., s. 98. 
może być oceniane jako obejmujące różne normy, nie tylko oceniane pozytywnie. W związku z tym nieuzasadnione wydaje się z jednej strony utożsamianie zasad współżycia społecznego tylko z zasadami ocenianymi pozytywnie z moralnego punktu widzenia, a z drugiej wyodrębnianie - w opozycji dla dobrych obyczajów - „złych” obyczajów ${ }^{85}$. Wydaje się, że obie klauzule odwołują się do pewnych zasad słusznego, przyzwoitego, uczciwego postępowania. W obu przypadkach chodzi o ocenę, czy dane zachowanie jest właściwe, słuszne w danych okolicznościach, czy można je pozytywnie ocenić. Odesłanie dotyczy więc „,dobrych”, słusznych zasad lub obyczajów, gdyż złych społeczeństwo nie kultywuje ${ }^{86}$. Tylko w takim ujęciu klauzule te mogą pełnić przypisywane im funkcje.

Niezależnie od kryterium uznanego za punkt odniesienia obie klauzule mają charakter względny, a ich treść zależy od kontekstu, w jakim są użyte. W związku z tym nie jest możliwe ustalenie katalogu takich zasad czy obyczajów. W praktyce stosowania prawa sądy również najczęściej nie wskazują, jaka zasada czy obyczaj zostały naruszone, lecz ograniczają się do stwierdzenia sprzeczności (czy zgodności) z zasadami współżycia społecznego lub dobrymi obyczajami. Klauzule te pełnią analogiczne funkcje: interpretacyjną (art. 65 k.c.), uzupełniającą (art. 56 k.c., art. 3 u.z.n.k.) oraz korygującą (art. 5, art. 58 § 1, art. $353^{1}$ k.c., art. 249, art. 422 k.s.h. $)^{87}$. Ich treść ma znaczenie drugorzędne z uwagi na zmienny charakter, zależny od zaistniałych in concreto okoliczności ${ }^{88}$, i stanowi funkcję czasu, miejsca oraz rodzaju stosunków, na tle których są one identyfikowane ${ }^{89}$.

Ponadto obie klauzule są klauzulami słusznościowymi, mają za cel realizację idei słuszności w prawie, w różny sposób umożliwiają przenikanie do prawa słuszności ujętej jako podstawowy katalog wartości akceptowanych w określonym systemie prawnym bądź grupie systemów prawnych o zbliżonej kulturze prawnej ${ }^{90}$. Ich rolą jest poszukiwanie ius aequum dla każdego konkretnego przypadku, kojarzenie dobra indywidualnego i wspólnego, realizacja postulatu pewności prawnej z niezbędną elastycznością w stosowaniu prawa ${ }^{91}$.

Interpretacja znaczenia (treści) tych klauzul w doktrynie i orzecznictwie charakteryzuje się tym, że przy wykładni zasad współżycia społecznego sięgano do dorobku judykatury i doktryny, powstałego na gruncie dobrych obyczajów, z ko-

85 Zob. Z. Ziembiński, Etyczne problemy..., s. 89 i n.; Z. Radwański, M. Zieliński, op. cit., s. 395.

${ }^{86} \mathrm{Na}$ okoliczność tę zwracają uwagę: B. Gadek, op. cit., s. 131; M. Pilich, op. cit., s. 172. Według R. Radwańskiego i M. Zielińskiego (op. cit., s. 395) zwrot „dobre obyczaje” sugeruje, że nie wszystkie obyczaje są dobre.

87 A. Piaskowy, Klauzule generalne w projekcie nowego kodeksu cywilnego, „Transformacje Prawa Prywatnego" 2012, nr 3, s. 58.

88 T. Justyński, op. cit., s. 99; E. Rott-Pietrzyk, Klauzula generalna rozsądku w prawie prywatnym, Warszawa 2007, s. 305-306.

89 T. Justyński, op. cit., s. 99; A. Koch, op. cit., s. 186; M. Pyziak-Szafnicka, op. cit., s. 905.

90 S. Grzybowski, Struktura i treść..., s. 27-30.

91 M. Safjan, op. cit., s. 51. 
lei przy interpretacji klauzuli dobrych obyczajów uzasadnione jest wykorzystanie dorobku judykatury i doktryny powstałego na gruncie klauzuli zasad współżycia społecznego (po jej odideologizowaniu).

\section{SPRZECZNOŚĆ Z ZASADAMI WSPÓŁŻYCIA SPOŁECZNEGO A SPRZECZNOŚĆ Z DOBRYMI OBYCZAJAMI W STOSUNKACH SPÓŁEK HANDLOWYCH}

W świetle powyższych uwag wydaje się, że na gruncie kodeksu spółek handlowych należy przyjąć, że klauzula „dobre obyczaje” jest odpowiednikiem klauzuli „zasady współżycia społecznego" występującej w kodeksie cywilnym.

Rozbieżności poglądów dotyczących istoty obu klauzul są konsekwencją występowania w nich zwrotów niedookreślonych. Ze względu na szeroki zakres stosowania tych klauzul najbardziej uzasadnione wydaje się uznanie, że wyznaczają one pewien model właściwego, uczciwego postępowania w stosunkach międzyludzkich. Stanowią pewien specyficzny konglomerat norm społecznych o zróżnicowanej proweniencji, zarówno mających uzasadnienie moralne, jak i obyczajowe, organizacyjne czy nawet ekonomiczne. W każdym przypadku odnoszą się do wartości powszechnie uznawanych w określonej grupie społecznej. Wskazywane między nimi różnice opierają się najczęściej na przyjętym a priori założeniu, że zasady współżycia społecznego to normy moralne, zaś dobre obyczaje to normy obyczajowe, czego konsekwencją jest wykazywanie dalszych między nimi rozbieżności. Tymczasem brak jest podstaw do przyjmowania takiego założenia. Ponadto w obu przypadkach klauzule te mogą być rozpatrywane jako wyznaczające pewien idealny wzorzec zachowania się, postępowania oraz jako normy (wartości) faktycznie stosowane w praktyce. Wydaje się, że w obu przypadkach objęte tymi klauzulami normy są powszechnie uznawane i przestrzegane. Ponadto odwołują się one do tych samych norm pozaprawnych, ocen opartych na tych samych wartościach, jakie są powszechnie akceptowane i wyrażone w Konstytucji. Nie istnieje jakakolwiek kolizja między odesłaniami do zasad współżycia społecznego a odesłaniami do dobrych obyczajów. Należy uznać, że powodują one takie same konsekwencje dla poszczególnych zdarzeń prawnych ${ }^{92}$.

W związku z tym różnica podstaw kształtowania granic swobody kontraktowej umowy lub statutu spółki handlowej w postaci dobrych obyczajów (art. $304 \S 4$ k.s.h.) i zasad współżycia społecznego (art. $353^{1}$ k.c. w zw. z art. 2 k.s.h.) nie powinna być postrzegana jako źródło rozbieżności między tymi granicami w przypadku statutu spółki akcyjnej oraz umów innych spółek. Postanowienie umowy spółki sprzeczne z zasadami współżycia społecznego jest nieważne zgodnie z art. $58 \S 2$ k.c. w zw. z art. 2 k.s.h. Sprzeczność postanowienia statutu spółki

92 Tak: Z. Radwański, M. Zieliński, op. cit., s. 399. 
akcyjnej z dobrymi obyczajami (art. $304 \S 4$ k.s.h.) również powoduje, że jest ono dotknięte nieważnością. W kontekście podstaw zaskarżania uchwał także należy przyjąć, że obie klauzule powinny być analogicznie interpretowane ${ }^{93}$, co oznacza, że uchwała sprzeczna z zasadami współżycia społecznego jednocześnie narusza dobre obyczaje, czyli podlega uchyleniu ${ }^{94}$. Trudno wskazać przypadki, gdy czynność prawną można uznać za sprzeczną z zasadami współżycia społecznego, ale nienaruszającą dobrych obyczajów czy też gdy czynność taka będzie sprzeczna z dobrymi obyczajami, ale zgodna z zasadami współżycia społecznego lub z ich punktu widzenia obojętna.

Ponadto należy uznać, że przepisy kodeksu spółek handlowych dotyczące podstaw (przesłanek) podważania uchwał zgromadzeń w spółkach kapitałowych stanowią $\mathrm{w}$ zakresie przez nie uregulowanym lex specialis wobec przepisów kodeksu cywilnego, zwłaszcza art. 58 k.c. ${ }^{95}$ Oznacza to, że nie ma podstaw do zastosowania tych ostatnich przez art. 2 k.s.h., skoro kwestie te zostały w sposób autonomiczny ujęte w k.s.h. W konsekwencji należy przyjąć, że uchwała sprzeczna z zasadami współżycia społecznego podlega uchyleniu jako sprzeczna z dobrymi obyczajami w razie zaistnienia dodatkowych wskazanych ustawowo przesłanek. Przewidziane tymi przepisami sankcje stanowią rozwiązania, do których wprost

93 Przemawiają za tym również wskazywane w doktrynie i orzecznictwie przejawy naruszenia dobrych obyczajów. Zob. A. Koch, op. cit., s. 192; wyrok SA w Poznaniu z dnia 27 sierpnia 1997 r., I ACa 386/97, OSG 1998, nr 6, poz. 75; wyrok SN z dnia 16 października 2008 r., III CSK 100/08, „Monitor Prawniczy” 2009, nr 22, s. 1232; wyrok SN z dnia 7 maja 2009 r., III CSK 315/08, LEX nr 512058; wyrok SN z dnia 5 listopada 2009 r., I CSK 158/09, OSNC 2010, nr 4, poz. 63; wyrok SN z dnia 6 marca 2009 r., II CSK 522/08, LEX nr 494003; wyrok SN z dnia 12 czerwca 2008 r., III CSK 8/08, „Monitor Prawniczy” 2009, nr 8, s. 443; wyrok SN z dnia 13 października 2004 r., III CK 459/02, prawo.legeo.pl.

${ }_{94}$ Tak: M. Spyra, op. cit., s. 502; J. Frąckowiak, op. cit., s. 688. Autorzy zwracają jednocześnie uwagę na pewne wątpliwości dotyczące utożsamiania tych pojęć. Odmiennie: S. Sołtysiński ([w:] System Prawa Prywatnego..., t. 17B, s. 601), który sprzeciwiając się utożsamianiu obu klauzul, uznaje, że nie jest wykluczone zaskarżenie uchwały sprzecznej z zasadami współżycia społecznego w drodze powództwa o stwierdzenie nieważności. Z kolei R.L. Kwaśnicki i M. Romanowska (Dopuszczalność zaskarżania uchwat zgromadzeń spółek kapitałowych na podstawie art. 58 § 2-3 oraz art. 59 kodeksu cywilnego, „Prawo Spółek” 2010, nr 9, s. 13) przyjmują, że sprzeczności uchwały z zasadami współżycia społecznego nie zostały uregulowane w k.s.h., w związku z tym dopuszczalne jest sięgnięcie do ogólnej normy art. 58 § 2 k.c. Zob. też: wyrok SN z dnia 25 lutego 2010 r., I CSK 384/09, „Monitor Prawniczy” 2011, nr 9, s. 497-498. A. Pęczyk-Tofel (Sprzeczne z ustawą uchwały zgromadzeń w spółkach kapitałowych, cz. 2, „Prawo Spółek” 2008, nr 10, s. 41) uważa, że sprzeczności z zasadami współżycia społecznego nie można uznać za sprzeczność z ustawą w rozumieniu art. 252 i 425 k.s.h. Taka uchwała może zostać zaskarżona w drodze powództwa o uchylenie uchwały, o ile spełnia jego przesłanki. Zob. też: wyrok SN z dnia 12 grudnia 2008 r., II CSK 278/08, LEX nr 520012.

95 Zob. uchwała SN z dnia 20 grudnia 2012 r. III CZP 84/12; wyrok SN z dnia 24 listopada 2004 r., II CK 210/04, „Biuletyn SN” 2005, nr 3, s. 13; wyrok SN z dnia 20 października 2011 r., III CSK 5/11, OSP 2012, nr 7-8 poz. 75. 
odsyła art. $58 \S 1$ k.c. Jest to w przypadku uchwały sprzecznej z zasadami współżycia społecznego (czyli dobrymi obyczajami), inny skutek", o którym mowa we wskazanym przepisie. Nie ma natomiast podstaw prawnych do konstruowania powództwa o stwierdzenie nieważności takiej uchwały niejako obok wskazanych w k.s.h. podstaw i trybu zaskarżenia. Zresztą wydaje się nieuzasadnione z uwagi na charakter obu klauzul i niedopuszczalne ze względów systemowych przyjęcie bezwzględnej nieważności uchwały sprzecznej z zasadami współżycia społecznego, a w przypadku sprzeczności z dobrymi obyczajami - możliwości uchylenia uzależnionej od spełnienia dodatkowych przesłanek ${ }^{96}$.

$\mathrm{W}$ razie dopuszczenia stosowania przepisów art. 58 k.c. do uchwał w zakresie nieuregulowanym w kodeksie spółek handlowych sprzeczność z zasadami współżycia społecznego mogłaby stanowić podstawę powództwa o stwierdzenie nieważności na ogólnych zasadach. Prowadzi to do konstruowania dość specyficznej w świetle przepisów k.s.h. podstawy takiego zaskarżenia w postaci art. 58 $\S 2$ k.c. w zw. z art. 2 k.s.h i w zw. z art. $252 \S 1$ lub art. $425 \S 1$ k.s.h., dla której brak jest normatywnego uzasadnienia, gdyż art. $252 \S 1$ oraz art. $425 \S 1$ k.s.h. wyraźnie odwołują się tylko do sprzeczności z ustawą. Tym bardziej wyłączona jest możliwość żądania stwierdzenia nieważności takiej uchwały na podstawie art. 189 k.p.c. ${ }^{97}$ ze względu na art. $252 \S 1$ in fine k.s.h. oraz art. $425 \S 1$ in fine k.s.h., które expressis verbis wyłączają zastosowanie tego przepisu. Na marginesie można w tym przypadku zadać pytanie o podstawę podważenia uchwały, która jest jednocześnie sprzeczna $z$ dobrymi obyczajami.

Na zakończenie warto zwrócić uwagę na zagadnienie wadliwości uchwały o zmianie statutu spółki akcyjnej, która przewiduje wprowadzenie postanowienia naruszającego dobre obyczaje, czy też uchwały o zmianie umowy spółki z o.o., wprowadzającej postanowienie o treści naruszającej zasady współżycia społecznego. Uchwałę taką można bowiem prima facie uznać za sprzeczną z dobrymi obyczajami, a tym samym podlegającą uchyleniu, o ile są spełnione wskazane w ustawie dodatkowe przesłanki. Wydaje się jednak, że wadliwość tej uchwały nie wyraża się w naruszeniu dobrych obyczajów czy zasad współżycia społecznego, lecz w naruszeniu art. $304 \S 4$ k.s.h., a przypadku spółki z o.o. - art. $353^{1}$ w zw. z art. 2 k.s.h., wskazujących granice swobody kształtowania treści statutu lub umowy spółki. W związku z tym wydaje się, że jest to uchwała sprzeczna z prawem i jako taka podlegająca powództwu o stwierdzenie nieważności.

96 Na marginesie można wskazać, że problem ten powstaje również na tle innych regulacji odwołujących się do klauzuli „dobre obyczaje”, które przewidują odmienny aniżeli nieważność bezwzględna skutek postanowienia umowy (np. art. $385^{1} \S 1$ k.c. dotyczący klauzul abuzywnych).

97 Ustawa z dnia 17 listopada 1964 r. - Kodeks postępowania cywilnego (t.j. Dz.U. z 2014 r., poz. $101 \mathrm{ze} \mathrm{zm}$.). 


\section{BIBLIOGRAFIA}

Allerhand M., Kodeks handlowy. Komentarz, t. 2, Bielsko-Biała 1991.

Bieniek T., Utworzenie spółki komandytowo-akcyjnej, „Prawo Spółek” 2001, nr 12.

Biskup R., Dobre obyczaje w działalności gospodarczej, „Annales: Etyka w Życiu Gospodarczym” 2007, $\mathrm{nr} 1$.

Bukowski T., Klauzule generalne w prawie cywilnym. O konieczności stworzenia katalogu zasad wspótzycia społecznego, „Monitor Prawniczy” 2008, nr 24.

Cetnarowicz M., Zasady wspólżycia społecznego a dobre obyczaje, „Ius Novum” 2007, nr 2-3.

Dajczak W., Zasady wspótżycia społecznego czy dobra wiara?, „Rejent” 2001, nr 1.

Dziurzyński T., Fenichel Z., Honzatko M., Kodeks handlowy. Komentarz, Łódź 1992.

Fenichel Z., Pojęcie „, dobrych obyczajów” w prawie polskim, Lwów 1934.

Frąckowiak J., [w:] Kodeks spółek handlowych. Komentarz, red. K. Kruczalak, Warszawa 2001.

Gadek B., Generalna klauzula odpowiedzialności za czyn nieuczciwej konkurencji (art. 3 u.z.n.k.), „Prace Instytutu Prawa Własności Intelektualnej Uniwersytetu Jagiellońskiego” 2003, nr 85.

Gasiński Ł., Granice swobody kształtowania treści statutu spółki akcyjnej, Warszawa 2014.

Grzesiok P., Zaskarżanie uchwat w kodeksie spótek handlowych na tle rozwiazań kodeksu handlowego, „Prawo Spółek” 2002, nr 5.

Grzybowski S., [w:] System Prawa Cywilnego, t. 1: Część ogólna, red. S. Grzybowski, Wrocław 1974.

Grzybowski S., Struktura i treść przepisów prawa cywilnego odsyłających do zasad wspólżycia społecznego, „Studia Cywilistyczne” 1965, t. 6.

Janiszewska B., Klauzula generalna dobrych obyczajów $w$ znowelizowanych przepisach kodeksu cywilnego, „Przegląd Prawa Handlowego” 2003, nr 10.

Janiszewska B., O potrzebie zmiany klauzuli zasad wspólzycia społecznego (głos w dyskusji), „Przegląd Ustawodawstwa Gospodarczego" 2003, nr 4.

Juszyński T., Nadużycie prawa w polskim prawie cywilnym, Kraków 2000.

Kępiński M., Problemy ogólne nowej ustawy o zwalczaniu nieuczciwej konkurencji, „Ruch Prawniczy, Ekonomiczny i Socjologiczny" 1994, nr 2.

Kidyba A., Kodeks spółek handlowych. Komentarz, t. 1, Warszawa 2013.

Kidyba A., Kodeks spółek handlowych. Komentarz, t. 2, Warszawa 2013.

Knypl T., Trzciński K., Znaczenie zwyczajów i dobrych obyczajów w prawie cywilnym $i$ handlowym, „Przegląd Prawa Handlowego” 1997, nr 8.

Koch A., Podważanie uchwat zgromadzeń spótek kapitałowych, Warszawa 2011.

Kopaczyńska-Pieczniak K., Spółka z ograniczona odpowiedzialnościa, Warszawa 2013.

Korzonek J., Rosenblüth I., Kodeks zobowiazań. Komentarz, Kraków 1934.

Kosikowski C., Ławicki T., Ochrona prawna konkurencji i zwalczanie praktyk monopolistycznych, Warszawa 1994.

Krauss A., Zoll F., Polska ustawa o zwalczaniu nieuczciwej konkurencji, Poznań 1929.

Kruczalak K., Prawo handlowe. Zarys wykładu, Warszawa 1997.

Kwaśnicki R.L., Autonomia woli w kształtowaniu postanowień umowy (aktu założycielskiego) spótki z o.o., „Prawo Spółek” 2003, nr 7-8.

Kwaśnicki R.L., Romanowska M., Dopuszczalność zaskarżania uchwał zgromadzeń spółek kapitałowych na podstawie art. 58 § 2-3 oraz art. 59 kodeksu cywilnego, „Prawo Spółek” 2010, nr 9.

Laszczyk A., Gajdus M., Wedle dobrych obyczajów czy zgodnie z zasadami wspótżycia społecznego? Uwagi na tle funkcjonowania klauzuli generalnej z Ustawy o zwalczaniu nieuczciwej konkurencji, „Przegląd Prawniczy Uniwersytetu im. Adama Mickiewicza” 2012, nr 1.

Leszczyński L., Dobre obyczaje zamiast zasad wspótżycia społecznego, „Rzeczpospolita” 1998, nr 26. Longchamps de Bérier R., Zobowiązania, Poznań 1948. 
Machnikowski P., Swoboda umów wedlug art. $353^{1}$ KC. Konstrukcja prawna, Warszawa 2005.

Monteskiusz, O duchu praw, przeł. T. Boy-Żeleński, Kęty 1997.

Nowińska E., Vall M. du, Komentarz do ustawy o zwalczaniu nieuczciwej konkurencji, Warszawa 2006.

Olejniczak A., [w:] Kodeks cywilny. Komentarz, t. 3: Zobowiązania. Część ogólna, red. A. Kidyba, Warszawa 2010.

Opalski A., Glosa do wyroku SN z dnia 27 marca 2013 r., I CSK 407/12, „Orzecznictwo Sądów Polskich" 2013, z. 11.

Pęczyk-Tofel A., Sprzeczne z ustawą uchwały zgromadzeń w spótkach kapitałowych, cz. 2, „Prawo Spółek" 2008, nr 10.

Piaskowy A., Klauzule generalne w projekcie nowego kodeksu cywilnego, „Transformacje Prawa Prywatnego" 2012, nr 3.

Pilich M., Zasady wspótżycia społecznego, dobre obyczaje czy dobra wiara? Dylematy nowelizacji klauzul generalnych prawa cywilnego w perspektywie europejskiej, [w:] Europeizacja prawa prywatnego, red. M. Pazdan, W. Popiołek, E. Rott-Pietrzyk, M. Szpunar, Warszawa 2008.

Popardowski P., Organy spółek kapitałowych i ich członkowie w najnowszym orzecznictwie Sądu Najwyższego, „Glosa” 2014, nr 1.

Poźniak-Niedzielska M., Kilka uwag o zachowaniu dobrych obyczajów w działalności gospodarczej, [w:] Iustitia civitatis fundamentum. Ksiega pamiatkowa ku czci Profesora Wiestawa Chrzanowskiego, red. H. Cioch, ks. A. Dębiński, J. Chaciński, Lublin 2003.

Preussner-Zamorska J., Problematyka klauzul generalnych na gruncie ustawy o zwalczaniu nieuczciwej konkurencji. Klauzula dobrych obyczajów w art. 16, „Kwartalnik Prawa Prywatnego" 1998, nr 4.

Promińska U., W sprawie relacji pomiędzy art. 3 a art. 16 ust. 1 pkt 1 u.z.n.k., [w:] Reklama. Aspekty prawne, red. M. Namysłowska, Warszawa 2012.

Pyziak-Szafnicka M., [w:] System Prawa Prywatnego, t. 1: Prawo cywilne - część ogólna, red. M. Safjan, Warszawa 2012.

Pyzioł W., [w:] Kodeks spółek handlowych. Komentarz, red. W. Pyzioł, Warszawa 2008.

Rachwał A., [w:] System Prawa Handlowego, t. 2A: Prawo spółek handlowych, red. S. Włodyka, Warszawa 2007.

Radwański Z., Olejniczak A., Zobowiq̨ania - część ogólna, Warszawa 2005.

Radwański Z., Zieliński M., [w:] System Prawa Prywatnego, t. 1: Prawo cywilne-część ogólna, red. M. Safjan, Warszawa 2012.

Rott-Pietrzyk E., Klauzula generalna rozsądku w prawie prywatnym, Warszawa 2007.

Rozporządzenie Prezydenta Rzeczypospolitej z dnia 27 czerwca 1934 r. - Kodeks handlowy (Dz.U., nr 57, poz. 502 ze zm.).

Rudnicki S., Reklama sprzeczna z dobrymi obyczajami lub uchybiająca godności człowieka, „Monitor Prawniczy" 1996, nr 1.

Ryan L.V., Wyzwania moralne w czasach transformacji gospodarczej, „Ruch Prawniczy, Ekonomiczny i Socjologiczny" 1996, nr 1.

Safjan M., Klauzule generalne w prawie cywilnym (przyczynek do dyskusji), „Państwo i Prawo” 1990, z. 11.

Sokołowska D., Statut spółki komandytowo-akcyjnej, [w:] Prawo handlowe po przystapieniu Polski do Unii Europejskiej, red. W.J. Katner, U. Promińska, Warszawa 2010.

Sołtysiński S., [w:] S. Sołtysiński, A. Szajkowski, A. Szumański, J. Szwaja, Kodeks spótek handlowych. Komentarz, t. 3, Warszawa 2008.

Sołtysiński S., [w:] System Prawa Prywatnego, t. 17B: Prawo spótek kapitałowych, red. S. Sołtysiński, Warszawa 2010.

Sołtysiński S., Nieważne i wzruszalne uchwały zgromadzeń spółek kapitałowych, „Przegląd Prawa Handlowego" 2006, nr 1. 
Spyra M., [w:] System Prawa Handlowego, t. 2B: Prawo spótek handlowych, red. S. Włodyka, Warszawa 2007.

Stefanicki R., Dobre obyczaje w prawie polskim, „Przegląd Prawa Handlowego” 2002, nr 5.

Stelmachowski A., Wstęp do teorii prawa cywilnego, Warszawa 1984.

Stelmachowski A., Zarys teorii prawa cywilnego, Warszawa 1998.

Stokłosa A., Glosa do wyroku SN z dnia 27 marca 2013 r., I CSK 407/12, „Przegląd Sądowy” 2014, nr 10.

Stokłosa A., Zaskarżanie uchwał zgromadzeń spótek kapitałowych. Glosa do wyroku Sądu Najwyższego z 27 marca 2013 r., I CSK407/12, „Przegląd Sądowy” 2014, nr 10.

Strzelczyk K., [w:] Kodeks spółek handlowych. Komentarz, red. T. Siemiątkowski, R. Potrzeszcz, t. 2, Warszawa 2011.

Szajkowski A., Tarska M., [w:] S. Sołtysiński, A. Szajkowski, A. Szumański, J. Szwaja, Kodeks spółek handlowych. Komentarz, t. 2, Warszawa 2005.

Szczurowski T., Wadliwość czynności prawnych spółek kapitałowych na tle sankcji kodeksu cywilnego, Warszawa 2012.

Szpunar A., Nadużycie prawa podmiotowego, „Polska Akademia Umiejętności. Prace Komisji Prawniczej" 1947, nr 2.

Szwaja J., [w:] S. Sołtysiński, A. Szajkowski, A. Szumański, J. Szwaja, Kodeks spótek handlowych. Komentarz, t. 2, Warszawa 2008.

Szwaja J., [w:] S. Sołtysiński, A. Szajkowski, A. Szumański, J. Szwaja, Kodeks spółek handlowych. Komentarz, t. 3, Warszawa 2008.

Szwaja J., [w:] Ustawa o zwalczaniu nieuczciwej konkurencji. Komentarz, red. J. Szwaja, Warszawa 2006.

Tarska M., Zakres swobody umów w spótkach handlowych, Warszawa 2012.

Trzaskowski R., Granice swobody ksztaltowania treści i celu umów obligacyjnych. Artykut $353^{l}$ K.C., Warszawa 2005.

Uchwała SN z dnia 20 grudnia 2012 r., III CZP 84/12, OSNC 2013, nr 7-8, poz. 83.

Ustawa z dnia 23 kwietnia 1964 r. - Kodeks cywilny (t.j. Dz.U. z 2014 r., poz. 121 ze zm.).

Ustawa z dnia 17 listopada 1964 r. - Kodeks postępowania cywilnego (t.j. Dz.U. z 2014 r., poz. 101 ze zm.).

Ustawa z dnia 16 września 1982 r. - Prawo spółdzielcze (t.j. Dz.U. z 2013 r., poz. 1443 ze zm.).

Ustawa z dnia 16 kwietnia 1993 r. o zwalczaniu nieuczciwej konkurencji (t.j. Dz.U. z 2003 r., nr 153, poz. 1503 ze zm.).

Ustawa z dnia 15 września 2000 r. - Kodeks spółek handlowych (t.j. Dz.U. z 2014 r., poz. 265 ze $\mathrm{zm}$.).

Ustawa z dnia 2 lipca 2004 r. o swobodzie działalności gospodarczej (t.j. Dz.U. z 2015 r., poz. 584).

Ustawa z dnia 23 sierpnia 2007 r. o przeciwdziałaniu nieuczciwym praktykom rynkowym (Dz.U., nr 171, poz. 1206).

Wajda D., Dobre obyczaje w spótkach kapitałowych, [w:] Prawo handlowe XXI wieku. Czas stabilizacji, ewolucji czy rewolucji. Księga jubileuszowa Profesora Józefa Okolskiego, red. M. Modrzejewska, Warszawa 2010.

Waligórski M.A., [w:] System Prawa Handlowego, t. 1: Prawo handlowe - czesść ogólna, red. S. Włodyka, Warszawa 2009.

Włodyka S., [w:] System Prawa Handlowego, t. 2A: Prawo spótek handlowych, red. S. Włodyka, Warszawa 2007.

Wolter A., Z zagadnień powiazania nauki prawa z praktyka, „Państwo i Prawo” 1954, z. 2.

Wolter A., Ignatowicz J., Stefaniuk K., Prawo cywilne. Zarys części ogólnej, Warszawa 2001.

Wyrok SA w Gdańsku z dnia 6 listopada 1996 r., I ACr 839/96, PG 1997, nr 6; OSA 1997, nr 10, poz. 57.

Wyrok SA w Gdańsku z dnia 29 maja 2014 r., I ACa 135/14, LEX nr 1504359. 
Wyrok SA w Katowicach z dnia 23 listopada 2006 r., I ACa 1373/06, LEX nr 307269.

Wyrok SA w Katowicach z dnia 28 czerwca 2007 r., V ACa 371/07.

Wyrok SA w Katowicach z dnia 26 marca 2009 r., V ACa 49/09, LEX nr 523888.

Wyrok SA w Katowicach z dnia 26 marca 2009 r., V ACa 49/09, OSA 2010, nr 7; LEX nr 523888.

Wyrok SA w Krakowie z dnia 15 listopada 2012 r., I ACa 1036/12, LEX nr 1236699.

Wyrok SA w Poznaniu z dnia 27 sierpnia 1997 r., I ACa 386/97, OSG 1998, nr 6, poz. 75.

Wyrok SA w Poznaniu z dnia 1 kwietnia 2014 r., I ACa 91/14, LEX nr 1493794.

Wyrok SA w Warszawie z dnia 10 maja 2013 r., VI ACa 157/12, LEX nr 1342422.

Wyrok SN z dnia 6 października 1998 r., II CKN 291/98, „Rejent” 1999, nr 5.

Wyrok SN z dnia 20 czerwca 2001 r., I CKN 1137/98, OSNC 2002, nr 3, poz. 31.

Wyrok SN z dnia 26 września 2002 r., III CKN 213/01, OSN 2003, nr 12, poz. 169.

Wyrok SN z dnia 13 października 2004 r., III CK 459/02, prawo.legeo.pl.

Wyrok SN z dnia 24 listopada 2004 r., II CK 210/04, „Biuletyn SN” 2005, nr 3.

Wyrok SN z dnia 8 marca 2005 r., IV CK 607/04, LEX nr 289387.

Wyrok SN z dnia 12 czerwca 2008 r., III CSK 8/08, „Monitor Prawniczy” 2009, nr 8.

Wyrok SN z dnia 16 października 2008 r., III CSK 100/08, „Monitor Prawniczy” 2009, nr 22.

Wyrok SN z dnia 16 października 2008 r., III CSK 100/08, OSNC - ZD 2009, nr 1 (A), poz. 30.

Wyrok SN z dnia 12 grudnia 2008 r., II CSK 278/08, LEX nr 520012.

Wyrok SN z dnia 6 marca 2009 r., II CSK 522/08, LEX nr 494003.

Wyrok SN z dnia 7 maja 2009 r., III CSK 315/08, LEX nr 512058.

Wyrok SN z dnia 5 listopada 2009 r., I CSK 158/09, OSNC 2010, nr 4, poz. 63.

Wyrok SN z dnia 25 lutego 2010 r., I CSK 384/09, „Monitor Prawniczy” 2011, nr 9.

Wyrok SN z dnia 25 lutego 2010 r., I CSK 384/09, OSNC 2010, nr 10, poz. 140.

Wyrok SN z dnia 20 października 2011 r., III CSK 5/11, OSP 2012, nr 7-8 poz. 75.

Wyrok SN z dnia 27 marca 2013 r., I CSK 407/12, OSP 2013, nr 11, poz. 108.

Wyrok SOKiK z dnia 23 lutego 2006 r., XVII Ama 118/04, Dz.Urz. UOKiK 2006, nr 2, poz. 31.

Zieliński T., Klauzule generalne $w$ nowym porzadku konstytucyjnym, „Państwo i Prawo” 1997, z. 11-12.

Ziembiński Z., Etyczne problemy prawoznawstwa, Wrocław 1972.

Ziembiński Z., Wstęp do aksjologii dla prawników, Warszawa 1990.

Zoll F., [w:] A. Krauss, F. Zoll, Polska ustawa o zwalczaniu nieuczciwej konkurencji, Poznań 1929.

Żurawik A., [w:] System Prawa Administracyjnego, t. 8A: Publiczne prawo gospodarcze, red. R. Hauser, Z. Niewiadomski, A. Wróbel, Warszawa 2013.

Żurawik A., Dobre obyczaje a zwyczaje, zasady wspólżycia społecznego i dobra wiara - ujęcie teoretyczne, „Kwartalnik Prawa Publicznego” 2007, nr 4.

Żurawik A., Klauzula generalna ,,dobrych obyczajów”- ujęcie teoretyczne, „Ruch Prawniczy, Ekonomiczny i Socjologiczny" 2009, nr 1.

\section{SUMMARY}

Both the general clause of rules of social conduct and the one of good practices apply in corporate relations - both internal and external ones. However, in internal relations of commercial companies, these clauses are accounted for to the same extent the provisions of the civil code are applied due to the nature of the legal relation of a commercial company (Art 2 of the Code of Commercial Companies). The diversity of opinions concerning the essence of both clauses results from the presence of indeterminate phrases in them. What is indicated in both cases is the reference to, primarily, moral and social norms, honesty and decency.

The specific concurrence of general rules of social conduct and good practices in the relations of commercial companies occurs when the same aspect is subject to appraisal in different compa- 
nies, applying one or the other clause. This is the consequence of the civil code applying mainly the clause of rules of social conduct whereas the code of commercial companies - the one of good practices, and the definition of the mutual relation of both codes as the one of lex generalis - lex specialis (Art. 2 of the Code of Commercial Companies). Such a concurrence of both clauses is primarily present on two planes: the appraisal of the scope of the freedom of contract in forming contracts of commercial companies (Art. 3 of the Code of Commercial Companies) and actions against company resolutions.

It seems that it needs to be adopted that as regards the code of commercial companies the clause of "good practices" is equivalent to the one of 'rules of social conduct' that is present in the Civil Code. Due to the wide scope of application of these clauses, it seems most justified to recognise that they establish a certain model of appropriate honest and decent conduct in human relations. They can be seen as a kind of a conglomerate of social norms of various origin, that is norms that can be justified on moral, social, organisational or even economic grounds.

Keywords: good practices; social conduct; commercial company

\section{STRESZCZENIE}

W stosunkach spółek handlowych - zarówno wewnętrznych, jak i zewnętrznych - znajduje zastosowanie klauzula generalna zasad współżycia społecznego i klauzula dobrych obyczajów. W stosunkach wewnętrznych spółek handlowych klauzule te jednak podlegają uwzględnieniu w takim zakresie, w jakim przepisy kodeksu cywilnego stosuje się z uwagi na naturę stosunku prawnego spółki handlowej (art. 2 k.s.h.). Rozbieżności poglądów dotyczących istoty obu klauzul są konsekwencją występowania w nich zwrotów niedookreślonych. W obu przypadkach wskazuje się na odesłanie przede wszystkim do norm moralnych, obyczajowych, uczciwości, przyzwoitości.

Specyficzny zbieg (konkurencja) klauzul generalnych zasad współżycia społecznego i dobrych obyczajów w stosunkach spółek handlowych występuje w przypadkach, gdy ten sam ich aspekt podlega ocenie w różnych spółkach przy wykorzystaniu jednej lub drugiej klauzuli. Stanowi to konsekwencję posługiwania się przez kodeks cywilny przede wszystkim klauzulą zasad współżycia społecznego, a przez kodeks spółek handlowych - klauzulą dobrych obyczajów oraz ujęcia wzajemnej relacji tych kodeksów jako lex generalis - lex specialis (art. 2 k.s.h.). Taka konkurencja obu klauzul jest widoczna przede wszystkim w dwóch płaszczyznach: oceny zakresu swobody umów przy kształtowaniu umowy spółki handlowej (art. 3 k.s.h.) oraz zaskarżania uchwał zgromadzeń w spółkach kapitałowych.

Wydaje się, że na gruncie kodeksu spółek handlowych należy przyjąć, że klauzula „dobre obyczaje” jest odpowiednikiem klauzuli „zasady współżycia społecznego”, występującej w kodeksie cywilnym. Ze względu na szeroki zakres stosowania tych klauzul najbardziej uzasadnione wydaje się uznanie, że wyznaczają one pewien model właściwego, uczciwego postępowania w stosunkach międzyludzkich. Można je uznać za pewien konglomerat norm społecznych o zróżnicowanej proweniencji, zarówno mających uzasadnienie moralne, jak i obyczajowe, organizacyjne czy nawet ekonomiczne.

Słowa kluczowe: dobre obyczaje; zasady współżycia społecznego; spółka handlowa 